\title{
Severe hyperglycaemia caused by autoimmunization to $\beta$ cells in rats
}

\author{
M.Ziegler, B.Ziegler and B. Hehmke \\ Central Institute of Diabetes 'Gerhardt Katsch', Karlsburg, GDR
}

\begin{abstract}
Summary. The non-specific activation of the immune system by administration of complete Freund's adjuvant was examined in Wistar rats as a possible means of amplification of the specific immune response directed to pancreatic $\beta$ cells caused by low dose non-diabetogenic multiple injections of streptozotocin. Rats were given intraperitoneally $0.5 \mathrm{ml}$ of complete Freund's adjuvant to induce polyclonal lymphocyte activation and, 1 day later, the animals were given an intraperitoneal injection of $15 \mathrm{mg}$ streptozotocin $/ \mathrm{kg}$ body weight (group 1). This combined treatment was given twice at weekly intervals. In two further groups, rats were treated with complete Freund's adjuvant alone (group 2) or streptozotocin alone (group 3) with the same doses and at the same times. Only the rats in group 1 developed delayed but severe and
\end{abstract}

persistent hyperglycaemia. In addition, significant complement-dependent cytotoxicity was detected in nine out of 15 rats $(60 \%)$ in group 1 in islet cells, but not in spleen lymphocytes. The pancreatic insulin content of the rats in group 1 was depleted by up to $3.1 \pm 0.5 \%$. With these experiments, a new animal model for insulin-dependent diabetes is described; complete Freund's adjuvant/streptozotocin diabetes. In many aspects, this model of diabetes parallels the development of insulin-dependent diabetes in man, including the humoral autoimmunity to islet cell antigens.

Key words: Insulin-dependent diabetes, rat, autoimmunization, streptozotocin, polyclonal lymphocyte activation.
Several factors, including the high prevalence of autoantibodies directed against islet cell antigens, suggest that autoimmune mechanisms may play an aetiological and pathogenic role in the development of Type 1 (insulin-dependent) diabetes in man $[1,2]$. An experimental model of diabetes in which autoimmune mechanisms have been proposed was first described by Like and Rossini [3, 4]. They showed that repeated injections of small subdiabetogenic doses of streptozotocin (STZ) $(40 \mathrm{mg} /$ body weight per day for 5 consecutive days) into susceptible mice strains caused delayed but progressive hyperglycaemia accompanied by insulitis. The possibility that low-dose STZ-induced insulitis might have an autoimmune component is of considerable interest, because insulitis is a histopathological finding associated with acute onset of Type 1 diabetes in man [5, 6]. Treatment of mice with an antiserum against mouse lymphocytes prevented both STZ insulitis and hyperglycaemia [7]. In contrast, Leiter et al. [8] found that functional T-lymphocytes are not required to mediate $\beta$-cell toxicity and concluded that, in this model, insulitis is a consequence of $\beta$-cell destruction rather than its cause.
In the present study, a new method was used to examine the involvement of an autoimmune component in $\beta$-cell destruction induced by non-diabetogenic doses of STZ in Wistar rats by the additional administration of complete Freund's adjuvant as a polyclonal lymphocyte activator in order to amplify the specific immune response.

\section{Materials and methods}

\section{Animals}

Seven-week old Wistar rats were used in all experiments. The rats were caged in groups of five to ten with free access to rat chow R13 (Rehbruecke, GDR) and water.

\section{Autoimmunization}

Seventeen rats were injected with $0.5 \mathrm{ml}$ complete Freund's adjuvant $24 \mathrm{~h}$ before STZ ( $15 \mathrm{mg} / \mathrm{kg}$ body weight, intraperitoneally; Upjohn, Kalamazoo, Michigan, USA, Lot 30295; group 1). This treatment was repeated twice at weekly intervals. Ten rats were treated with complete Freund's adjuvant alone (group 2) and five rats with STZ alone (group 3 ) with the same doses and at the same times. 
Table 1. Induction of complement-dependent cytotoxicity to islet cells in plasma samples and nearly complete depletion of pancreatic insulin on experimental day 56 by combined treatment with complete Freund's adjuvant and low doses of streptozotocin

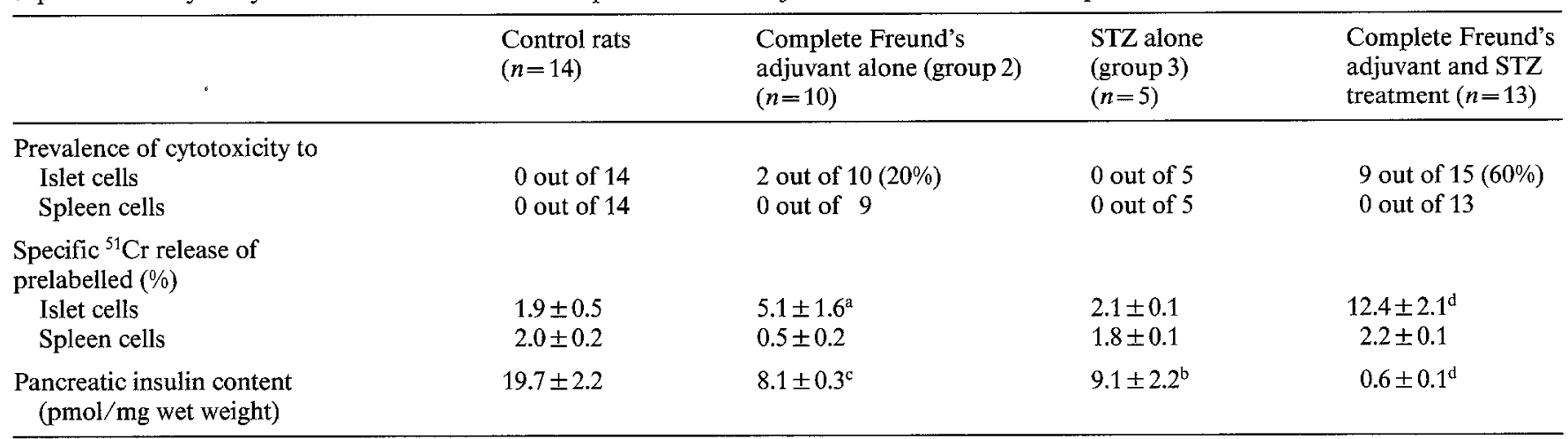

Data are expressed as mean \pm SEM. ${ }^{\mathrm{a}} p<0.05 ;{ }^{\mathrm{b}} p<0.02 ;{ }^{\mathrm{c}} p<0.01 ;{ }^{\mathrm{d}} p<0.0001$



Fig. 1. Induction of severe, persistent hyperglycaemia by combined administration of complete Freund's adjuvant and low doses of streptozotocin. Group 1: $\left(n=13, \mathrm{O}^{-} \mathrm{O}\right)$; rats treated intraperitoneally with $0.5 \mathrm{ml}$ complete Freund's adjuvant (CFA) $24 \mathrm{~h}$ before intraperitoneal injection of STZ $(15 \mathrm{mg} / \mathrm{kg}$ body weight) three times at weekly intervals. Group 2: $(n=10 ; \Delta-\Delta)$ rats treated with complete Freund's adjuvant alone. Group $3(n=5 ; \square-\square)$ rats treated with STZ alone. Both groups 2 and 3 were treated at the same concentrations and the same times as group 1. Each point represents the mean $\pm S E M$ non-fasting plasma glucose level for each group. The shaded area constitutes the mean \pm SD plasma glucose level for the control rats $(n=57)$

\section{Determination of plasma glucose levels}

Blood samples were obtained from non-fasting animals between 06.00 and $07.00 \mathrm{~h}$ and plasma glucose concentration was assayed by the glucose-oxidase method in a Beckman glucose analyser (Beckman Instruments, Fullerton, California, USA).

\section{Determination of pancreatic insulin content}

Each pancreas was dissected free of fat, weighed, homogenized and extracted with acid ethanol [9]. Immunoreactive insulin activity (IRI) was determined by radioimmunoassay using commercial kits (Isocommerz, GDR) and a rat insulin standard (Novo, Copenhagen, Denmark).

\section{${ }^{51}$ Cr release cytotoxicity}

Neonatal rat islet cells or spleen lymphocytes were labelled with $\mathrm{Na}_{2}{ }^{51} \mathrm{Cr} \mathrm{O}_{4}$ (Zentralinstitut für Kernforschung, Dresden, GDR) as described previously [10]. Labelled islet cells $\left(1-2 \times 10^{5}\right)$ or lymphocytes $\left(1-2 \times 10^{6}\right)$ were incubated with $0.025 \mathrm{ml}$ of heat-inactivated plasma samples. After $30 \mathrm{~min}$, plasma proteins were removed by washing and $0.05 \mathrm{ml}$ of a $1: 4$ diluted rabbit complement was added for another $30 \mathrm{~min}$ incubation at $37^{\circ} \mathrm{C}$ (prior to use, non-specific complement cytotoxicity was removed by adsorption with packed neonatal rat spleen cells at a volume ratio of $1: 1$ at $4{ }^{\circ} \mathrm{C}$ for $5 \mathrm{~h}$ ). Aliquots of the supernatant were counted in a gamma counter (LKB, Bromma, Sweden). The specific ${ }^{51} \mathrm{Cr}$ release was calculated from the formula:

$\frac{\mathrm{cpm}_{\text {experimental release }}-\mathrm{cpm}_{\text {spontaneous release }}-2 \times \mathrm{cpm}_{\text {background }}}{\mathrm{cpm}_{\text {maximum release }}-\mathrm{cpm}_{\text {background }}} \times 100$

Spontaneous release was below $10 \%$ in all experiments. For the determination of maximum release, prelabelled islet cells and lymphocytes were lysed with $0.5 \%$ Triton X-100 (Ferak).

\section{Statistical analysis}

Statistical significance was determined by the Student's t-test.

\section{Results}

\section{Severe hyperglycaemia}

Three injections of a non-diabetogenic dose of STZ $(15 \mathrm{mg} / \mathrm{kg}$ body weight) given at weekly intervals 1 day after complete Freund's adjuvant administration caused delayed, persistent hyperglycaemia in 15 out of 17 rats studied for 143 days (Fig. 1). Injections of complete Freund's adjuvant (group 2) or STZ (group 3) alone had no effect on plasma glucose.

\section{High prevalence of cytotoxicity for islet cells}

Plasma samples of nine out of 15 hyperglycaemic rats $(60 \%)$ in group 1 and of two out of ten $(20 \%)$ euglycaemic rats (group 2) caused a significantly increased ${ }^{51} \mathrm{Cr}$ release of prelabelled islet cells in the presence of complement (Table 1). Only the mean value of the specific 
${ }^{51} \mathrm{Cr}$ release $(12.4 \pm 2.1 \%)$ caused by plasma samples of rats from group 1 was significantly increased $(p<0.01)$. The ${ }^{51} \mathrm{Cr}$ release of islet cells was not enhanced in the plasma of STZ-treated rats $(2.1 \pm 1.0 \%)$ versus that of control rats $(1.9 \pm 0.5 \%)$. No cytotoxicity to spleen cells was found in any plasma sample under the same conditions.

\section{Almost complete depletion of pancreatic insulin}

Only $3 \%(0.6 \pm 0.1 \mathrm{pmol} / \mathrm{mg})$ of the normal pancreatic insulin content $(19.7 \pm 2.2 \mathrm{pmol} / \mathrm{mg})$ was detected in group 1 on day 56 (Table 1). The pancreatic insulin was also significantly reduced in group 2 by $59 \%(8.1 \pm 0.3$ $\mathrm{pmol} / \mathrm{mg})$ and in group 3 by $54 \%(9.1 \pm 2.2 \mathrm{pmol} / \mathrm{mg})$ versus control animals. However, the pancreatic insulin in group 1 was very significantly lower than that of groups 2 or 3 .

\section{Discussion}

Our results demonstrate that the induction of insulindependent diabetes in Wistar rats treated with low doses of STZ $(3 \times 15 \mathrm{mg} / \mathrm{kg}$ body weight) requires the participation of autoimmune processes against pancreatic $\beta$ cells. Only rats pretreated with complete Freund's adjuvant in order to produce polyclonal lymphocyte activation became hyperglycaemic after injections of low doses of STZ. Furthermore, the high prevalence of complement-dependent cytotoxicity to islet cells in nine out of $15(60 \%)$ rats in group 1 suggested that immune mechanisms might be involved in the induction of persistent hyperglycaemia in this new animal model. No cytotoxicity to spleen lymphocytes was detected in any plasma sample.

The $\beta$ cell specificity of the autoimmune response is supported by the fact that pancreatic insulin was almost completely depleted while the glucagon content was not reduced (unpublished data). With these experiments, a new animal model for Type I diabetes in man is introduced. There is some evidence that STZ acts primarily on the $\beta$-cell membrane [11]. Thus, $\beta$-cell surface neoantigens may be generated, and an immune response against these autoantigens may be amplified by the presence of complete Freund's adjuvant. It is suggested that complete Freund's adjuvant alters the equilibrium between helper and suppressor $\mathrm{T}$ cells, resulting in an enhanced helper T-cell effect [12]. Islet cell autoantibodies were not found in the low-dose STZ-induced diabetes in mice [13].

However, the complement-dependent cytotoxicity to islet cells in plasma samples from complete Freund's adjuvant-STZ treated rats demonstrated the prevalence of islet cell surface antibodies in this diabetes model.
Surprisingly, the pancreatic insulin content of group 2 was also significantly reduced by up to $41 \%$ versus that of the control group. Furthermore, two out of ten rats in this group showed a significant cytotoxicity to islet cells, but not to spleen cells. This phenomenon allows us to speculate that the immune self-tolerance for islet cell antigens is less stable than for other self-antigens and is overcome by a strong non-specific stimulation of the immune system [14].

Acknowledgements. We are grateful to S. Tietz, Ch. Kauert and W. Wassmann for technical assistance, E.Heiden for typing and J. Fanning for the linguistic correcting of the manuscript.

\section{References}

1. Lernmark A, Freedman ZR, Hofmann C, Rubenstein AH, Steiner DR, Jackson RE, Winter RJ, Traisman HS (1978) Islet cell surface antibodies in juvenile diabetes mellitus. $\mathrm{N}$ Engl $\mathrm{J}$ Med 229: 375-380

2. Bottazzo GF, Florin-Christensen A, Doniach D (1974) Islet cell antibodies in diabetes mellitus with autoimmune polyendocrine deficiencies. Lancet 2: 1279-1282

3. Like AA, Rossini AA (1976) Streptozotocin-induced pancreatic insulitis: a new model of diabetes mellitus. Science 193: 415-417

4. Rossini AA, Like AA, Chick WL, Appel MC, Cahill GF (1977) Studies of streptozotocin-induced insulitis and diabetes. Proc Natl Acad Sci USA 74: 2485-2489

5. Gepts W (1965) Pathologic anatomy of the pancreas in juvenile diabetes mellitus. Diabetes 14: 619-633

6. Paik SG, Blue ML, Fleischer N, Shin S (1982) Diabetes susceptibility of Balb/cBom mice treated with streptozotocin. Inhibition by lethal irradiation and restoration by splenic lymphocytes. Diabetes 31: $808-815$

7. Rossini AA, Williams RM, Appel MC, Like AA (1978) Complete protection from low-dose streptozotocin-induced diabetes in mice. Nature 276: 182-184

8. Leiter EH, Beamer WG, Schultz LD (1983) The effect of immunosuppression on streptozotocin-induced diabetes in $\mathrm{C} 57 \mathrm{BL} / \mathrm{KsJ}$ mice. Diabetes 32: 148-155

9. Ziegler M, Krabiell U, Georgi M (1977) Verfahren zur Isolierung von Peptiden und Eiweißen. DDR-Wirtschaftspatent, Patentschrift 125998: 1-5 (Patent office of GDR)

10. Hehmke B, Kohnert K-D, Dietz H, Zühlke H (1982) Cytotoxic effects of islet cell surface antibodies. Acta Biol Med Germ 41: $1117-1122$

11. Orci L, Amherdt M, Malaisse-Lagae F, Ravazzola M, Malaisse WJ, Perrelet A, Renold AE (1976) Islet cell membrane alteration by diabetogenic drugs. Lab Invest 34: 451-454

12. Osebold W (1982) Mechanisms of action by immunologic adjuvants. J Am Vet Med Assoc 181: 983-987

13. Riley WJ, McConnell TJ, Maclaren NK, McLaughlin JV, Taylor $G$ (1981) The diabetogenic effects of streptozotocin in mice are prolonged and inversely related to age. Diabetes $30: 718-723$

14. Kolb H, Freytag G, Kiesel U, Kolb-Bachofen V (1981) Cellular immune reactions against pancreatic islets as a consequence of graft versus host disease. Clin exp Immunol 43: 121-127

Dr. M.Ziegler

Central Institute of Diabetes 'Gerhardt Katsch'

DDR-2201 Karlsburg

GDR 